\title{
THE INFLUENCE OF FACTORS OF MIGRATION ON THE MIGRATION STATUS OF RURAL-URBAN MIGRANTS IN DHAKA, BANGLADESH
}

\author{
Asif Ishtiaque*, Md. Sofi Ullah \\ Department of Geography \& Environment, University of Dhaka, Bangladesh
}

\begin{abstract}
There are several factors, responsible for rural-urban migration, influence the migrant's migration status. The main objective of this paper to discuss the influence of migration factors on the determination of migration status of the rural-urban migrants'. As a case study, this study purposively selected the largest slum of Bangladesh according to single criterion- high concentration of rural-urban migrants. A total of 263 face to face interviews and 5 FGDs were conducted. Respondents, who are household heads of the migrant families, were chosen randomly and interviewed using both open ended and close ended questionnaires and for data analyses, respondents were categorized into two divisions- temporary and permanent migrants. Multivariate analyses show that both push and pull factors influence the migration status of migrants', however, social factors, except occupation at rural origin, do not have any considerable influences.
\end{abstract}

Key words: Rural-urban migration, Migration status, Influence of migration factors, Bangladesh, Dhaka.

Article Info: Manuscript Received: May 6, 2013; Revised: October 18, 2013; Accepted: November 11, 2013; Online: November $20,2013$.

\section{Introduction}

Rural-Urban migration, the most crucial component of internal migration of any country, is a powerful symbol for regional inequality, in terms of economy, opportunities and living standards (Islam 2006). Development of cities is intrinsically related with migration, especially with rural-urban migration, as the huge labor requirement of urban centers is fulfilled by the labors from the rural areas (Harris 1970). Migration can be broadly defined as the change of residence from one civil division to another for a specific period of time or on a permanent basis. Migration occurs for various reasons and its determinants or factors vary from country to country and even within a country; it varies depending on the socio-economic, demographic and cultural factors. High unemployment rate, low income, high population growth, unequal distribution of land, demand for higher schooling, previous migration patterns and displeasure with housing have been identified as a number of the prominent determinants of rural out migration (Billsborrow et al., 1987; Nabi, 1992; Sekhar, 1993;

* Corresponding author:

Address: C/O: Sheikh Mofizul Islam, Executive Secretary, Bangladesh National Social Welfare Council, 4/A Eskaton Garden, Dhaka- 1000, Bangladesh.

Telephone: +8801915163578

Email: asif_ishti@yahoo.com
Yadava, 1988; Singh and Yadava, 1981). Migration is often considered as a driver of growth and an important route out of poverty with significant positive impact on people's livelihoods and wellbeing (Anh, 2003). There is a general consensus that migration and remittances reduce rural poverty and contribute to the improvement of household living standards.

For Todaro (1969) and Harris and Todaro (1970), rural-urban migration in less developed countries depends on the difference in expected wage from migration (urban wage) versus an agricultural wage. As rural-urban migration often coexist with high levels of urban unemployment, Johnson (1971) introduced to the Harris-Todaro model a "wage sharing" variable to take into account urban unemployment and a lower rate of job turn over. Gugler and Flanagan (1978), Fields (1975), and Kelly and William (1984) suggested an inclusion in the Harris-Todaro model of the differential access to information for rural workers and urban residents, the cost of living, and education levels when computing the probability of a migrant securing an urban job. Corden and Findlay (1975) focused on capital mobility (i.e., workers moving to places where capital is more productive) as a major determinant of labor migration. In general, all the authors agreed on the basic Todaro hypothesis that wage differentials guide rural-urban migration. 
In the developing country like Bangladesh population mobility is a necessary condition for sustainable development and poverty alleviation (Islam, 1996a). Poverty and physical mobility are closely interrelated and migration towards urban centers becomes an important livelihood diversification strategy for the poor groups of any country (Berner, 200o). This picture is clearly depicted in Dhaka, the only megacity of Bangladesh. It is the fastest growing urban center in Bangladesh.

Dhaka joined 'megacity' rank in 2001 with a population of 10.7 million (BBS, 2003). Dhaka now holds 14.65 million populations in an area of 1530 square kilometers and becomes the world's $9^{\text {th }}$ largest megacity (UN 2009). Between 1990 and 2005, the city doubled in size - from 6 to 12 million (Burkart, 2008). Dhaka is the fastest growing megacity in the world, with an annual growth rate of 4.4 per cent per year (UN-HABITAT, 2008). In 2025 Dhaka will become the $5^{\text {th }}$ largest megacity (UN, 2009). According to UN-HABITAT (2006), by 2020, Mumbai, Delhi, Mexico City, Sao Paulo, New York, Dhaka, Jakarta and Lagos all will have achieved metacity status (Metacity, or hypercity, is an epithet that refers to massive sprawling conurbations of more than 20 million people. Tokyo became the first hypercity in the mid-1960s when it crossed the 20 million threshold). By 2025 Dhaka will be home of 22.02 million people - larger than Mexico City, Beijing or New York (UNHABITAT, 2008). However, Dhaka has increased 35 times in last 6o years and this increase is occurring mainly due to high level of urban in-migration. Studies have also shown that more than 6o per cent of population increase in Dhaka, Bangladesh, is due to in-migration (Pantelic, 200o). Migration and redefinition of urban boundaries contribute three-fifth and two-thirds respectively to the urban growth of Bangladesh for the last four decades (Afsar, 200o).

Dhaka megacity is the most popular destination for the poor groups of the country and every year rural people pour into Dhaka city nearly at a rate of 400,00o each year (German, 2010). In Dhaka more than $37 \%$ of city's population live in slums (CUS, 2006) and almost all them are rural poor migrants and for this reason Dhaka is now considered as 'city of urban poor' (Islam, 2001).

Todaro's wage differential hypothesis is evident in Dhaka as migrants mostly come to Dhaka for economic factors (Afsar 2000, Ullah 2004), to diminish the gap between their needs and gains (Ishtiaque 2011). But most often there remain a lifelong links between these urban migrants and their rural origins as most of the time only the household head, leaving behind their families in their rural origins, migrate to this megacity. Bartle (1981) termed this phenomenon as 'an extended community' and Gugler (1991) referred to as 'living in a dual system.'

\section{Studies on Rural-Urban Migration in Bangladesh}

Although migration towards urban centers is a historical phenomenon in Bangladesh, but unfortunately there remains a lack of migration data from secondary sources. The census data of Bangladesh is not sufficient to study migration as these possess only some information about place of birth. These seriously hinder the analysis of migration. However, a number of descriptive studies, which explore migration general characteristics, were done by CUS in 1983, 1988, 1990 and by Islam (1996a). Chaudhury (1975) found that at least $39.36 \%$ of the total urban population came from rural areas.

Stoeckel et. al. (1977) examined the dynamics of rural out migration and they concluded that out migration from rural areas are selective in age, gender, occupation, household size etc. Chaudhury (1980) found that out-migration, depending on population density and geographical location, is generally higher from the villages characterized by land scarcity, unequal land distribution and high proportion of agricultural labor. But, however, Nabi (1992) argued that the internal migration flows in Bangladesh are not determined by high population density rather the unequal hierarchical relations of people to the land in Bangladesh condition the process by which migration takes place.

Mahbub (1997) noticed that, finding the circulatory nature of the rural-urban migrants, the rate of movement in future would be dominated by the mobility of the lower classes within space and time. Afsar (2000), however, found out that migrants often benefited more than non-migrants because of their innovative, risk taking and desperate nature. The benefits included higher or regular income, gain in wealth, greater access to public services and education (Hossain, 2001). Kinship act as a social insurance in Bangladesh society (Kuhn, 2003) and as a result, it is not surprising that close relatives, who are overseas or in urban areas, play a vital role in meeting the cost of passage for new migrants (Islam 1983, Rahman 2005). Thus past rural-urban migrants encourage current migrants and this is sometimes called 'path dependence' (Hatton 1998). They also establish linkages to their relatives and friends both at destination and at origin (Islam 2006).

Majumdar et al. (1989), Amin (1986) and Rokib (2009) studied the socio-economic and demographic consequences of migration based on sample surveys, while Ishtiaque (2011) discussed the migration objectives fulfillment of rural-urban migrants' based on case study. It has been found that rural-urban migrants are relatively better educated than the national population (Saleheen, 1980). Huq-Hossain (1996) found that the rural migrants in the city are hard working and contribute significantly in daily life. 
Studies have shown that both rural poor and nonpoor migrate to urban areas (Chowdhury 1978 and Mandola 2005). Bhuyan (2001) examined that the process of rural-urban migration is strongly influenced by the incidence of push factors, while Ullah (2004) found that migration is influenced by both push and pull factors. According to Ullah (2004), due to PEST factors (political, economic, social and technological) people are more likely to move and Ishtiaque (2011) showed that people from south-eastern and north-eastern part are less likely to move to Dha$\mathrm{ka}$, as two major industrial cities, Chittagong and Sylhet, are situated there.

After doing a rigorous literature review we have found that the influence of push and pull factors over the migration status' has not yet been focused in the previous literatures. To fulfill this gap in this paper we have focused on the influence of push and pull factors, along with some other social determinants, over the migration status. Thus the objective of this paper is to discuss how push and pull factors influence the migration status of a migrant.

\section{Methods}

\section{Study Area Selection}

This study was conducted in 2011 in one single slum. As in most cases slum is the final destination of ruralurban migrants (Ullah, 2004), Korail slum, the largest slum of Bangladesh, have been selected as the study area purposively, according to one single criteriahigh concentration of rural-urban migrants.

Actually the link between migration and slums has been of concern since it has become apparent that the majority of Asia's population (56\%) will be living in urban areas by the year 2020 (Islam 1996b). Slum is a very popular destination of rural-urban migrants. City life is comparatively expensive than the rural life and so that most of the migrants cannot afford the expense to live in urban residential areas. In that case they go to slums, where living expense is comparatively lower, which are generally situated beside the manufacturing areas of a city. Bangladesh, like several Asian countries, has a high general prevalence of slum households, but unlike many others, slum prevalence in its capital Dhaka and other large cities is higher than in its small cities and towns (UNHABITAT 2008). There are total 9048 slum communities in the 6 divisional cities of Bangladesh. And more than 5.4 million people live in those slums. Dhaka megacity alone contains 4966 slums where about 3.4 million people live (CUS 2006).

Lloyd (1979) found that $94 \%$ of slum dwellers in Dhaka were from rural areas, while Majumder (1996) and Qadir (1975) put the figure at 93\%. Ullah (2004) found about $91 \%$ of the rural-out migrants' final des- tination is slum or squatter settlement. In Dhaka more than $37 \%$ of the total city population lives in slums and the slum population density is 220,246 persons per $\mathrm{km}^{2}$ (CUS 2006).

\section{Data Collection and Analysis}

Respondents were chosen using a random sampling procedure (Cochran 1963) and only the household head was selected as respondent. The survey was a combination of both open ended and closed questions as recommended by De Vaus (1991) for good survey design. A total of 263 respondents were interviewed face to face and a total of 5 FGDs were employed to collect data. Respondents were carefully selected from all over the slum and it is ensured that the respondents' locations were not clustered in a specific portion of the slum. Most of the respondents are older than 30 years, uneducated and left the rural areas at their mid 2os. However, interview questions were formulated in a careful manner. Interview questions ranged from general information, like age, local origin, time of migration etc., to specific information of the household like migration reason, objectives, occupation etc. These questions were asked to get a lucid picture of a migration case- from the reasons to leave rural origin to fulfill the migration objectives at urban destination. All face to face interviews were transcribed and qualitatively analyzed to identify the common themes (Dunn 2000). For data analyses, interviewed migrants were broadly divided into two categories- temporary and permanent. Temporary migrants, including the seasonal, circular migrants also, are those who don't have a plan to settle down in Dhaka rather they want to make some or enough money in Dhaka and then return to their rural origin. On the other hand, permanent migrants have willingness to stay in Dhaka, buying a piece of land at the periphery or a small home at suburb, forever. Multivariate techniques were used for data analyses.

\section{Results}

To discuss the influence of factors of migration over migration status, we should, at first, know the determinants which coerce the rural dwellers to migrate. In Bangladesh people migrate to cities mostly for economic reasons (Nabi 1992, Hossain 2001, Islam 2006) as well as for natural disasters (Mahbub 1988, Herrmann 2009). Ullah (2004) found that flow of migration to the major cities in Bangladesh is the result of rural - urban dichotomies in income, employment opportunity and absorptive capacity while Rokib (2009) showed that religion, educational qualification and occupation of the household head have positive direct effects on migration. On the other hand, Herrmann (2009) argued that the principle 
factor that encourages people to leave their homes in the country side is the frequent recurrence of natural disasters, which undermine agricultural development and cause food crisis. In case of urban attraction, there is a consensus that the most dominant factor is high employment opportunity in the urban centers (Stoeckel 1972, Chaudhury 1980, Huq-Hossain 1996, Afsar 2000, Bhuyan 2001, Hossain 2001, Islam 2006, Ishtiaque 2011). It can be deduced that economic reasons play as both predominant push and pull factor in rural-urban migration and in some cases environmental reasons also become a significant push factor.

\section{Logistic Regression Analysis}

The interview session revealed a bunch of determinants that led the migrants to decide to move to Dhaka. In this part of interview, the respondents were free to identify the key determinants which compel or attract them to migrate. No list was given to the respondents, rather a list of factors was prepared after analyzing the interviews. Hence, these factors will be considered as potential factors which influence migration status of the migrants.

List of factors prepared after analyzing the interviews:

$f_{1}=$ Natural Disasters (i.e. river bank erosion, cyclone)

$\mathrm{f}_{2}=$ Lack of Employment Opportunity

$\mathrm{f}_{3}=$ Lack of Food/Crop Failure

$\mathrm{f}_{4}=$ Financial Crisis

$\mathrm{f}_{5}=$ Landlessness

$\mathrm{f}_{6}=$ Higher Income Probability

$\mathrm{f}_{7}=$ Maladjustment in Family/Community

$\mathrm{f}_{8}=$ Influence of Family Members

$\mathrm{f}_{9}=$ Being Evicted from Land

$\mathrm{f}_{10}=$ Availability of Jobs

$\mathrm{f}_{11}=$ Getting Access to City's Informal Economy

$f_{12}=$ 'Dhaka means Taka' Conception/Bright City Lights

$\mathrm{f}_{13}=$ Joining Families

$\mathrm{f}_{14}=$ Age (during migration)

$\mathrm{f}_{15}=$ Marital Status (during migration)

$\mathrm{f}_{16}=$ Education (in years)

$\mathrm{f}_{17}=$ Occupation (at rural origin)

A regression model has been generated using the factors as 'independent variables' and migration status as 'dependent variable'. Factors with comparatively higher frequencies have been included in this model. The following independent factors have shown considerable correlation, at $95 \%$ level of confidence, with the dependent variable 'migration status', and help to minimize the number of factors that show potential factors. Factors, entered into the final model, are natural disaster $\left(f_{1}\right)$, lack of employment opportunity $\left(f_{2}\right)$, financial crisis $\left(f_{4}\right)$, influence of family members $\left(f_{8}\right)$, availability of jobs $\left(f_{10}\right)$, getting access to city's informal economy $\left(f_{11}\right)$, 'Dhaka means
Taka' conception/bright city lights $\left(f_{12}\right)$, occupation at rural origin $\left(f_{17}\right)$. The variables, with a correlation coefficient smaller than o.10, were removed from the model to maximize the relation between independent (factors) and dependent (migration status) variables.

Table 1. Regression Coefficients

\begin{tabular}{|c|c|c|}
\hline Variables & $\begin{array}{l}\text { Regression } \\
\text { Coefficients }\end{array}$ & Significance \\
\hline Constant & 423.033 & 0.045 \\
\hline Natural Disaster $\left(\mathrm{f}_{1}\right)$ & 0.325 & 0.021 \\
\hline $\begin{array}{l}\text { Lack of Employment } \\
\text { Opportunity }\left(\mathrm{f}_{2}\right)\end{array}$ & 0.392 & 0.023 \\
\hline Financial Crisis $\left(\mathrm{f}_{4}\right)$ & 0.411 & 0.021 \\
\hline $\begin{array}{l}\text { Influence of Family } \\
\text { Members ( } f 8 \text { ) }\end{array}$ & 0.282 & 0.022 \\
\hline Availability of Jobs $\left(f_{10}\right)$ & 5.463 & 0.011 \\
\hline $\begin{array}{l}\text { Getting Access to City`s } \\
\left.\text { Informal Economy (f } f_{11}\right)\end{array}$ & 5.504 & 0.012 \\
\hline $\begin{array}{l}\text { "Dhaka means Taka" } \\
\text { conception / Bright City } \\
\text { Lights }\left(f_{12}\right)\end{array}$ & 6.851 & 0.014 \\
\hline $\begin{array}{l}\text { Occupation at Rural } \\
\text { Origin }\left(f_{17}\right)\end{array}$ & 0.939 & 0.031 \\
\hline
\end{tabular}

Source: Computed from Surveyed Data

$$
\begin{aligned}
& Y=423.033+0.325 * f_{1}+0.392 * f_{2}+0.411 * f_{4}+0.282{ }^{*} f_{8^{+}} \\
& 5.463{ }^{*} f_{10}+5.504 * f_{11}+6.851^{*} f_{12}+0.939 * f_{17}
\end{aligned}
$$

Here ' $\mathrm{Y}$ ' is dependent variable 'migration status'. The $\mathrm{R}^{2}$ value is 0.829 , which shows the significance of this model in analyzing the factors that influence in the process of determination of migration status.

From the regression model we can deduce that amongst all responsible factors $f_{10}$ (availability of jobs), $f_{11}$ (getting access to city's informal economy) and $f_{12}$ ('Dhaka means Taka' conception/bright city lights) have quite significant influence on dependent variable as the regression coefficients are comparatively higher. The rural areas lack enough employment opportunity which compels the inhabitants to migrate to Dhaka for employment, better earning. Moreover, the lucrative features of capital Dhaka also influence the migration status decision of a migrant.

\section{Factor Analysis}

Factor analysis has been employed for data reduction in dimension. Factors, influencing migration status, have been extracted through this analysis. The determinants are characterized by three major categories: urban pull factors, rural push factors and social factors. The cumulative percentage of the variances of these factors is 78.51, which implies that the determi- 
nants could reasonably be sufficient to explain the determination of migration status process. Urban pull factors, explaining $35.11 \%$ of the total variance, is the most dominant factor in this case. This is represented as a positive correlation (factor loadings) with the following factors:

Table 2. Urban Pull Factors

\begin{tabular}{|l|c|}
\hline \multicolumn{1}{|c|}{ Variable } & Factor Loadings \\
\hline Availability of Jobs $\left(\mathrm{f}_{11}\right)$ & .812 \\
\hline $\begin{array}{l}\text { Getting Access to City`s Informal } \\
\text { Economy }\left(\mathrm{f}_{11}\right)\end{array}$ & .907 \\
\hline $\begin{array}{l}\text { “Dhaka means Taka” conception / } \\
\left.\text { Bright City Lights ( } \mathrm{f}_{12}\right)\end{array}$ & .907 \\
\hline \% Variance & $35.11 \%$ \\
\hline Eigen value & 4.565 \\
\hline
\end{tabular}

Source: Computed from Surveyed Data

Table 3. Rural Push Factors

\begin{tabular}{|l|c|}
\hline \multicolumn{1}{|c|}{ Variables } & Factor Loadings \\
\hline Natural Disaster $\left(\mathrm{f}_{1}\right)$ & .889 \\
\hline Lack of Employment Opportunity $\left(\mathrm{f}_{2}\right)$ & .898 \\
\hline Lack of Food / Crop Failure $\left(\mathrm{f}_{3}\right)$ & .759 \\
\hline Financial Crisis $\left(\mathrm{f}_{4}\right)$ & .937 \\
\hline $\begin{array}{l}\text { Maladjustment in Fami- } \\
\text { ly/Community }\left(\mathrm{f}_{7}\right)\end{array}$ & .730 \\
\hline Influence of Family Members $\left(\mathrm{f}_{8}\right)$ & .835 \\
\hline \% Variance & $26.46 \%$ \\
\hline Eigen value & 3.439 \\
\hline
\end{tabular}

Source: Computed from Surveyed Data

Table 4. Social Factors

\begin{tabular}{|l|c|}
\hline \multicolumn{1}{|c|}{ Variables } & Factor Loadings \\
\hline Age (during migration) $\left(\mathrm{f}_{14}\right)$ & .401 \\
\hline Marital status (during migration) $\left(\mathrm{f}_{15}\right)$ & .351 \\
\hline Education (in years) $\left(\mathrm{f}_{16}\right)$ & .489 \\
\hline Occupation (at rural origin)( $\left.\mathrm{f}_{17}\right)$ & .636 \\
\hline \% Variance & $16.94 \%$ \\
\hline Eigen value & 2.202 \\
\hline
\end{tabular}

Source: Computed from Surveyed Data

Rural push factors account for $26.46 \%$ and social factors for $16.94 \%$ of the total variances. The findings here are similar to the regression analysis. In both analyses although both push and pull factors predominantly influence the determination of migration status, urban pull factors are comparatively significant. It is evident that financial factors, both as push and pull factor, play significant role in migrants' migration status determination.

\section{Discussion}

This study found that about $52 \%$ of the respondents are temporary migrants, whereas $48 \%$ are permanent. Most of the permanent migrants had plans to buy a piece of land at the suburb and reside there permanently. In their words, as they would not get any job or financial opportunity in the village anyway, there was nothing that will attract them to return to it. Although they had no intention to cut off their relationship with the village altogether they would rather treat revisiting it as an outing. Temporary migrants, on the other hand, have a plan to make some money in Dhaka and thus develop their rural belongings and finally after a certain period of time, in most cases they don't know when, return to their origins. This study found that the migrants' determination of migration status is considerably influenced by eight factors: natural disasters, lack of employment opportunity, financial crisis, influence of family members, availability of jobs, getting easy access to city's informal economy, bright city lights, occupation at rural origin. Although Saleheen (1980) and Rokib (2009) found out that education has direct effect on migration, this study found that education, age and marital status have not any significant influence over migration status, however, this study agrees with Afsar (2000) and Rokib (2009) that occupation at rural origin has significant impact on migrants.

Bangladesh is a natural disaster prone country. Cyclones in 1970 and 1991 killed 300,000 and 170,000 people respectively, and in 2007 a category- 5 cyclone, Sidr, hit Bangladesh killing about 5000 people (Rasheed, 2008). One of the predominant reasons that cause homelessness, landlessness of rural people is riverbank erosion and this disaster is so devastating that even an affluent farmer in a village can be a landless man over one night. These natural disasters compel people to migrate to cities with their families, as they lost all their belongings. According to this study, about $10 \%$ of the respondents migrate due to natural disasters where $70 \%$ of them migrate permanently.

Easy access to city's informal economy is one of the most dominant forces of attraction of urban centers. In Bangladesh, based on 2010 LFS (Labor Force Survey), the unemployment rate in Bangladesh is only $4.5 \%$. Of the employed population, $87.43 \%$ is in informal sectors, which was $78.48 \%$ in LFS 2005-06 and $79.23 \%$ in LFS 2002-03 (BBS, 2012). In Dhaka division $83.1 \%$ of the employed population is in informal sectors (BBS, 2008b). Workers employed in the informal sectors increased by about $8 \%$ from the 1970 s to 1980 os (Amin 1994). In 1988, there were more than 500,000 rickshaw-pullers in Dhaka; a number that had increased to about 900,0oo by the year 2002 (Ullah 2004). City's informal jobs include rickshaw pulling, hawker activities, roadside small business, 
day laboring etc. In the rural areas of Bangladesh many people still believe that Taka (currency of Bangladesh) flies in the air of Dhaka and people, who are in senile stage of their lives, inspire the young generation to move to Dhaka to earn their breads. This study found about $68 \%$ of the respondents, among them about $47 \%$ is permanent, is somehow influenced by the opportunities to get involve in city's informal economy or the bright city lights.

Another important factor, which determines migration status, is availability of jobs in industrial sectors of urban areas. In this study, however, about 22\% of the permanent migrants showed lack of job as the prime factor to have reluctance to return village. Actually rapid growth of export oriented garment industries, particularly in large cities has been a major contributor to urban pull (Nazem, 2011). The major concentration of RMG (ready made garment) industries took place in Dhaka $(74 \%)$ followed by Chittagong (22\%) (Islam 2008). It is believed that more than 500 ,ooo skilled and unskilled workers are employed in RMG industries. Not only that, Dhaka division has 16414 manufacturing industries, which is $47.29 \%$ of all industries in the country (BBS 2008a), and most of these industries are located in urban centers, especially in Dhaka megacity. For this reason people are more likely to move Dhaka, than to other urban centers, and Dhaka has to face a high influx of migrants every year.

Actually Bangladesh is going through a transitional period, from agriculture based society to manufacture based society. At present $28 \%$ of total population of Bangladesh is living (UNFPA 2010), and in 2037 more than $50 \%$ of the population will live in urban centers (Islam 2006). The annual rate of the national population increase is $1.40 \%$ whereas the urban population growth rate is $3.20 \%$ (Population Reference Bureau, 2010). From 2000 to 2005, the contribution of natural increase of urban population was only $41.9 \%$ while that of rural-urban migration and redefinition of urban centers was about 58.1\% (Afsar 200o). This represents that a huge proportion of rural-urban migrants has started to live in the urban areas permanently. This study also found that almost half of the total respondents migrate permanently.

It is evident that employment in agricultural sector is decreasing every year, in 2002-03 LFS it was $51.7 \%$ while in 2010 LFS it became $47.3 \%$. (BBS 2012). In case of contribution in GDP, in 2011 agricultural sector contributes only $19.95 \%$, which was $20.16 \%$ in 2010, while service sector and manufacturing sector together contribute $68.13 \%$ (BBS 2011). In cases of rural and urban areas, in 1991-92 urban sectors' contribution to GDP was $38 \%$, which was only $25 \%$ in $1972-73$ and o6\% in 1961 (Haq 1997). Recently, however, urban sector's share to GDP is estimated at about $60 \%$ (CUS 2010). Government's policies have focus on the growth of urban centers, especially growth of three or four cities, whereas employment generation in rural areas is being neglected since the independence of Bangladesh and that is why rural people have to come to cities in search of money. It is indisputable that Dhaka is the nucleus of Bangladesh, in terms of employment opportunity, educational, health and other basic civic facilities. These features of Dhaka attract people from all over the country and this huge influx of people will soon turn this megacity into metacity.

Although there is huge number of migrants comes to Dhaka each year but the megacity's urban infrastructure has not the capacity to absorb this huge. That is why more than one-third of the megacity's population lives in slums and squatters. The rural areas of Bangladesh lack both economic and social opportunities and the existing condition of migration suggests that the government should introduce more employment opportunities in rural areas and adopt a balanced development strategy to encourage settlements and other functions in small and intermediate cities. Creating more employment opportunities in the rural areas through establishing the small scale factories and RMG industries as well as social investment would be an effective measure to lessen the enormous migration flow towards Dhaka and to ensure a sustainable development.

\section{Conclusion}

In this study nearly half of the total respondents are permanent migrant and the determination of migration status is highly influenced by urban pull factors, such as availability of jobs, getting access to informal economy, influence of bright city lights. Rural factors also play significant role, however, social factors, except occupation at rural origin, are not significant comparatively. This study has found that not only the migration but the determination of migration status also follows the basic Todaro model of wage differentials. Although this model was devised over 40 years ago, the core concept is similar even at present. Rural areas of Bangladesh still has agriculture dominated economy, and, like Harris-Todaro model, the difference between agriculture wage and urban wage played the most significant role in the decision making- whether the migrant will leave urban areas. Financial reasons, acting as push or pull factor, are the principal reasons behind taking the migration status decision. Job availability, informal economy, city lights all these factors are economic related.

This study tried to focus on various migration factors that influence the migrant's migration status. The result of this study was unique in terms of the main theme- influence of migration factors over migration status, as there was no study in Bangladesh covers this topic. However, previous studies in Bang- 
ladesh emphasized on variables influencing migration but none of them did discuss the influence of these factors on migration status. In this way this paper contributes to address a research gap.

\section{Acknowledgement}

The authors would like to thank Center for Urban Studies (CUS), Department of Geography \& Environment, University of Dhaka and Bangladesh Bureau of Statistics (BBS) for giving convenient access to their libraries. Valuable suggestions of Balkumar K. C., Chairman at Institute of Population and Development Studies, Nepal, are thankfully acknowledged.

\section{References}

Afsar, R 2000, Rural-Urban Migration in Bangladesh: Causes, Consequences and Challenges, University Press Limited, Dhaka.

Amin, ATMN 1994,'Economics of rural - urban relations reexamined in the light of growing environmental concerns', Regional Development Studies, vol. 1, pp. 27- 54.

Amin, ATMN 1986,'Urban Informal Sector: Employment Potentials and Problems' in R Islam \& M Muqtada (eds), Bangladesh: Selected Issues in Employment and Development, ILO, ARTEP, New Delhi.

Anh, DN 2003,'Migration and Poverty in Asia: With reference to Bangladesh, China, the Philippines and Viet Nam', paper presented at Ad Hoc Expert Group Meeting on Migration and Development, Economic and Social Commission for Asia and the Pacific, 27-29 August, Bangkok.

BBS (Bangladesh Bureau of Statistics) 2003, Population Census 2001, National Report (Provisional), Ministry of Planning, Government of Bangladesh, Dhaka.

BBS (Bangladesh Bureau of Statistics) 2008a, Report on Survey of Manufacturing Industries 2005-06, Ministry of Planning, Government of Bangladesh, Dhaka.

BBS (Bangladesh Bureau of Statistics) 2008b, Annual Labor Force Survey 2005-06, Ministry of Planning, Government of Bangladesh, Dhaka.

BBS (Bangladesh Bureau of Statistics) 2011, Economic Census 2010, Ministry of Planning, Government of Bangladesh, Dhaka.

BBS (Bangladesh Bureau of Statistics) 2012, Annual Labor Force Survey 2009-10, Ministry of Planning, Government of Bangladesh, Dhaka.

Bartle, PFW 1981,'Cyclical migration and extended community: a West African example', in RB Mandal (ed), Frontiers in Migration Analysis, Concept Publishing Co., New Delhi.

Berner, E 2000,'Poverty alleviation and the eviction of the poorest: towards urban land reform in the Philippines', International Journal of Urban and Regional Research, vol. 24, no. 3, pp. 554-566.

Bhuyan, AR, Khan, H \& Ahmed, SU 2001, Rural Urban Migration and Poverty: The Case for Reverse Migration in
Bangladesh, MAP Focus Study Series 10. Centre on Integrated Development for Asia and the Pacific, Dhaka.

Billsborrow, RE, McDevitt, TM, Kassoudji, S \& Fuller, R 1987, The Impact of Origin Community Characteristics on Rural-urban Out-migration in a Developing Country, Demography, vol. 24, no. 2, pp. 191-210.

Burkart, K, Gruebner, O, Khan, MMH, Staffeld, R 2008,'Megacity Dhaka: urban environment, informal settlements and public health', Geographische Rundschau, vol. 4, no. 1, pp. 5-10.

Chaudhury, RH 1978,' Determinants of and Consequences of Rural Out Migration: Evidence from Some Villages in Bangladesh', Oriental Geographer, vol. 22, no. 1 \& 2, pp. 120.

Chaudhury, RH 1980, Urbanisation in Bangladesh, CUS, University of Dhaka, Dhaka.

Chaudhury, RH \& Curlin, GC 1975, Dynamics of Migration in a Rural Area of Bangladesh, BIDS, Dhaka.

Cochran, WG 1963, Sampling Techniques, $2^{\text {nd }}$ edn, John, Wiley and Sons, New York.

Corden, WM, Findlay, R 1997,'Urban Unemployment Intersectorial Capital Mobility and Development Policy', Economica, pp. 59-78.

CUS (Centre for Urban Studies) 1983, Slums in Dhaka CityA Socio-Economic Survey for Feasibility of Slum Clearance and Urban Renewal Programme in Dhaka City, Centre for Urban Studies, University of Dhaka, Dhaka.

CUS (Centre for Urban Studies) 1988, Slums and Squatters in Dhaka City, Centre for Urban Studies, University of Dhaka, Dhaka.

CUS (Centre for Urban Studies) 1990, The Urban Poor in Dhaka, vol 1. Comprehensive Summary Report, Centre for Urban Studies, University of Dhaka, Dhaka.

CUS 2006, Slums of Urban Bangladesh: Mapping and Census, 2005, Centre for Urban Studies, University of Dhaka, Dhaka.

CUS 2010, City Cluster Economy Development Case Study: Dhaka Capital Region, Bangladesh, CUS, Dhaka.

De Vaus, DA 1991, Surveys in social research, 3rd edn, Allen and Unwin, London.

Dunn, K 2000,'Interviewing' in I Hay (ed), Qualitative Research Methods in Human Geography, Oxford University Press, New York.

Fields, GS 1975,'Rural-Urban Migration, Urban Unemployment and Underemployment and Job Search Activity in LDCs', Journal of Development Economics, vol. 2, pp. 165188.

German, E \& Pyne, S 2010, Disasters drive mass migration to Dhaka, Global Post, viewed on September 8, http://www.globalpost.com/dispatch/asia/100831/banglad esh-megacities-part-three-migrant.

Gugler, J \& Flanagan, WG 1978, Urbanization and social change in West Africa, Cambridge University Press, New York.

Gugler, J 1991,'Life in a dual system revisited: urban-rural ties in Enugu, Nigeria, 1961-1987, World Development, vol. 19, no. 5, pp. 399-409.

Haq, ATMZ 1997, Contribution of the Urban Sector to the Economy of Bangladesh' in N, Huda, N, Islam, F, Narayan \& PB Rana (eds), Addressing Urban Poverty Agenda in Bangladesh: Critical Issues and 1995 Survey Findings, UPL, Dhaka. 
Harris, JR \& Todaro, MP 1970,'Migration, Unemployment and Development: A Two-sector Analysis', The American Economic Review, vol. 6o, no. 1, pp. 126-38.

Hatton, TJ \& Williamson, JG 1998, The Age of Mass Migration- Causes and Economic Impact, Oxford University Press, Oxford.

Herrmann, M \& Svarin, D 2009, Environmental pressures and rural-urban migration: The case of Bangladesh, MPRA Paper No. 12879, http://mpra.ub.uni-muenchen.de/12879/

Hossain, MZ 2001, Rural-Urban Migration in Bangladesh: A Micro Level Study', presented at the $21^{\text {st }}$ Conference of Bangladesh Association for the Advancement of Science (BAAS), Dhaka.

Huq-Hossain, S 1996,'Female Migrant's Adaptation in Dhaka: A Case of the Process of Urban Socio-Economic Change', Oriental Geographer, vol. 39, no. 1 \&2, pp. 86-105.

Ishtiaque, A \& Mahmud, MS 2011,' Migration objectives and their fulfillment: A micro study of the rural-urban migrants of the slums of Dhaka city', Geografia: Malaysian Journal of Society and Space, vol. 7, no. 4, pp. 24-29.

Islam, N 1996a, Dhaka: From City to Mega City, Urban Studies Program, Dhaka.

Islam, N 1996b, The state of the urban environment in Bangladesh' in N Islam \& RM Ahsan (eds), Urban Bangladesh, Urban Studies Program, Dhaka.

Islam, N \& Saleheen, M 2006, Rural-Urban Linkage and Migration Issue in Bangladesh: A Secondary Literature Study, Centre for Urban Studies.

Islam, N 2008,'Bangladesh' in B Roberts \& T Kanaley (eds), Urbanization and Sustainability in Asia, ADB, Philippines.

Islam, N \& Begum, J 1983, Internal Migration in Bangladesh: A Review of Literature, Monograph No. 9, CUS, Dhaka.

Islam, N (ed) 2001, Urbanization, urban planning and development and urban governance: A reader for students, Center for Urban Studies, Dhaka.

Johnson, G 1971,'The Structure of Rural-Urban Migration Models', East Africa Economic Review, vol. 3, no. 1, pp. 2138.

Kelly, AC \& Williamson, JG 1984, What Drives Third World City Growth? A Dynamic General Equibrium Approach, The Princeton University Press, New York.

Kuhn, RS 2003, 'Identities in Motion: Social Exchange Networks and Rural-Urban Migration in Bangladesh' in Contribution to Indian Sociology, 37 (1-2), pp. 311-337.

Lloyd, P 1979, Slums of hope? Shanty Towns of the Third World, Manchester University Press, Manchester.

Mahbub, AQM 1997, Mobility Behaviour of Working People in Bangladesh: Rural-Rural and Rural-Urban Circulation, Urban Studies Programme, Department of Geography and Environment, University of Dhaka, Dhaka.

Mahbub, AQM \& Islam, N 1988,'Urban Adjustment by Erosion Induced Migrants', Paper on the Impact of Riverbank Erosion, Flood Hazard and the Problem of Population Displacement, Dhaka, Bangladesh.

Majumder, PP, Mahmud, S \& Afsar, R 1996, The squatters of Dhaka city: dynamism in the life of Agargaon squatters, University Press Limited, Dhaka.

Majumder, PP, Afsar, R \& Mahmud, S 1989, Squatter Life in Agargaon Area, Bangladesh Institute of Development Studies, Dhaka.
Mandola, M 2005, Migration and Technological Change in Rural Households: Compliments or Substitutes?, Working paper number 15. Deipartimanto di Scienze Ecomomiche, Aziendali e Statistiche Universita degli studi di Milano, Milano, Italy.

Nabi, AKMN 1992,' Dynamics of Internal Migration in Bangladesh', Canadian Studies in Population, vol. 19, no. 1, pp. 81-98.

Nazem, NI 2011,'Urbanization in Bangladesh: Pattern and Process', paper presented at Bangladesh Urban Forum, 5-7 December, 2011, BUF.

Pantelic, J 2000, Urban-rural synergies and poverty alleviation: The case of Bangladesh, The World Bank Group, Washington, DC.

Population Reference Bureau 2010, 2010 World Population Data Sheet.

Qadir, SR 1975, Bustees of Dacca: a study of squatter settlements, Local Government Institute, Dhaka.

Rahman, MM \& Lee, LK 2005, Bangladeshi Migrant Workers in Singapore: The View from Inside', Asia Pacific Population Journal, vol. 20, no. 1, pp. 63-88.

Rasheed, KBS 2008, Bangladesh- Resources and Environmental Profile, A H Development Publishing House, Dhaka.

Rokib, A \& Islam, R 2009,'Effect of Some Selected Sociodemographic Variables on Male Migrants on Bangladesh', Current Research Journal of Economic Theory, vol. 1, no. 1, pp. 10-14.

Saleheen, MU 1980, The Significance of Internal Migration in Population Redistribution of Bangladesh', International Population Symposium on Development and Population Redistribution in South Asia, IGU Commission on Population Geography, University of Karachi, Karachi, Pakistan.

Sekhar, TV 1993,'Migration Selectivity from Rural Areas: Evidence from Kerala', Demography India, vol. 22, no. 2, pp. 191-202.

Singh, SN \& Yadava, KNS 1981,' On Some Characteristics of Rural Outmigration in Eastern Uttar Pradesh', Society and Culture, vol. 12, no.1, pp. 33-46.

Stoeckel, J, Chowdhury, AKMA \& Aziz, KMA 1972,'Out Migration from a Rural Areas of Bangladesh', Rural Society, vol. 37, no. 2.

Todaro, MP 1969;'A model of labour migration and urban unemployment in less developed countries', The American Economic Review, vol. 59, pp. 138-148.

Ullah, AKMA 2004,'Bright City Lights and Slums of Dhaka City: Determinants of Rural-Urban Migration in Bangladesh', Migration Letters, vol. 1, no. 1, pp. 26-41.

United Nations 2009, World Urbanization Prospect: The 2009 Revision, Department of Economic and Social Affairs, Population Division.

UNFPA 2010, State of World Population 2010, UNFPA.

UN-HABITAT 2006, State of the World's Cities 2006/7, UNHABITAT.

UN-HABITAT 2008, State of the World's Cities 2008/9Harmonious Cities, UN-HABITAT.

Yadava, KNS 1988, Determinants, Patterns and Consequences of Rural-Urban Migration in India, Independent Publishing Company, Delhi. 